\begin{tabular}{l|l|l|l|l}
\hline Volume 1 & Issue 3 & December (2020) & DOI: 10.47540/ijsei.v1i3.99 & Page: $174-181$ \\
\hline
\end{tabular}

\title{
Street Vendors Based on Tribal Groups in Kendari City, Indonesia
}

\author{
Ashmarita \\ Department of Anthropology, Faculty of Humanities Universitas Halu Oleo, Indonesia
}

Corresponding Author: Ashmarita; Email: ashmarita@gmail.com

\begin{tabular}{ll}
\hline A R T I C L E I N F O & A B S T R A C T \\
$\begin{array}{l}\text { Keywords: Ethnicity; Stereotype; } \\
\text { Strategy; Street Vendors (PKLs) }\end{array}$ & $\begin{array}{l}\text { The main impact of urbanization is to increase urban population density. Increased } \\
\text { investment in the industrial sector has opened up job opportunities in various } \\
\text { sectors, including the informal sector. Street vendors (PKLs) are one of the informal } \\
\text { Received : } 01 \text { October 2020 }\end{array} \quad \begin{array}{l}\text { sector jobs that are often found in plural urban communities. The plurality of the } \\
\text { Revised }: 29 \text { November } 2020\end{array} \quad \begin{array}{l}\text { population in society creates different perceptions in terms of the type of work they } \\
\text { accepted engaged in. This study aims to (1). Identify the socio-economic characteristics } \\
\text { of PKLs; (2). Identify the strategies used by street vendors in maintaining their } \\
\text { existence. This research is a descriptive-qualitative study obtained from interviews } \\
\text { and direct observations of PKLs in Kendari. The informants were determined } \\
\text { purposively. The analysis data is performed by compiling the data then interpreted } \\
\text { by referring to the relationship between various concepts and social realities. The } \\
\text { results showed that the street vendors in Kendari were generally villagers. They } \\
\text { moved to Kendari because the village where they lived was considered no longer } \\
\text { representative of their survival. PKLs are generally urban mobility actors who live } \\
\text { on the edge of Kendari. To maintain their existence, they perform various ways, } \\
\text { including by strengthening ties between ethnic groups, improving services, finding } \\
\text { strategic locations, and making cheaper 'counter' products. }\end{array}$ \\
\end{tabular}

\section{INTRODUCTION}

Urbanization has become a major problem in countries with very large populations, such as China, India, and Indonesia. The World Bank (2012) notes that Indonesia is one of the developing countries with the largest urban population in Southeast Asia. About $49.8 \%$ of the population lives in big cities and it is estimated that it will reach $68 \%$ by 2025 . One of the main problems of urbanization is the increasing population density in the cities (Robert and Kanaley, 2006). The large concentration of the urban population has changed the lifestyle, social structure, and work of the community (Robert and Kanaley, 2006).

Urbanization in developing Southeast Asian countries has been triggered by increased investment in the industrial sector (Elias and Noone, 2011). This condition led to a transformation in urban communities, which initially depended on the agricultural sector, to the industrial and service sectors. The development of the industrial and service sectors encourages informal factors which are the "way of life" for urban communities to survive (Irianto, 2014).

Difficulty finding work is a common problem in urban areas. The low quality of prospective workers in terms of education and skills makes it difficult for them to find jobs in the formal sector. Some physical developments in the formal sector sometimes do not have a significant impact on the lowly community (Handoyo and Setiawan, 2018). People who do not have workplaces in the formal sector are already working in the informal sector to meet the needs of their families. One of the most informal sectors found in urban communities is PKL.

Regardless of the pros and cons, PKLS has become part of urban life. PKLS are a consequence of the high level of urbanization (Boonstra, 2011) and the large economic responsiveness of the community (Handoyo and Widyaningrum, 2015). Urban economic disparities of the poor, unskilled and uneducated population have limited options for survival. They depend their lives on PKLS (Maneepong and Walls, 2013), PKLS are a strategy 
for survival (Handoyo and Setiawan, 2018) in the face of global economic uncertainty (Sariffudin, 2017).

Naim (1984) explains that trade is an informal sector that is in great demand by migrant residents. Their limited education and lack of skills are the main reasons for them to choose this profession (Nursyirwan, 1997). Trader is a profession that is easier to do than having to be a driver,] carpenter, mason, and various other informal jobs that require special skills. Traders only need capital and the ability to speak to attract buyers' sympathy without having to spend a lot of energy, thought, and time. In addition, the profits earned are higher than other informal sectors. Cangara (1999) explains that the lack of proper connections and adequate qualifications of migrant populations causes them to find less attractive jobs. They end up working as fringe laborers or as shopkeepers with wages below the minimum standard and can be dismissed on occasion.

Kendari city is a pluralistic area inhabited by various tribes from various regions with different cultures. A plural society provides the potential for the emergence of various stereotypes on the choice of employment opportunities. In the selection of employment opportunities, each tribe seems to have a tendency towards certain types of work. For example, the Bugis people dominate the grocery trading, the Javanese sell vegetables and seafood, the Munanese sell fruit, the Butonese sell clothes and accessories, and so on. Based on the description above, this study aims to identify the socioeconomic characteristics and strategies of the street vendors in maintaining their survival.

\section{MATERIALS AND METHODS}

This research is qualitative. In connection with the idea of Molong (2015), this paper produces descriptive-qualitative data obtained from interviews or direct observations of PKL's behavior in the field. The descriptive data found will reveal in detail and in-depth a systematic and accurate picture of the facts in the field (Bungin, 2015). The descriptive-qualitative method is used so that the author can provide an understanding, explanation, and theory of the social behavior of PKLs. This method is also expected to be able to provide a complete explanation of the complexity of the system, behavior, needs, and culture that is built up between PKL. Qualitative data obtained in this study were obtained through observations of traders, especially PKLs.

This research was conducted in Kendari City, which is the center of trade, the center of the crowd, and the capital of Southeast Sulawesi Province. This research was conducted in several places, namely Wet Market Mandonga Mall, Kendari Beach Area, and MT. Haryono street. These locations were chosen because they are the center of trade and hustle in the city of Kendari.

PKLs as informants are determined directly during a visit to three predetermined locations. The determination of informants in this study was carried out purposively (Maxwell, 1996, Creswell, 2007), with considerations based on criteria, it is considered that they know and willing to provide information relevant to the focus of the study. At the beginning of the research, a meeting was held with the key informant, namely LM. Taslim Suri to determine which informants can provide information relevant to the research theme. Taslim Suri is known as Bang Bram among PKLs. He is the coordinator of BAMPER (Barisan Masyarakat Pedagang Ekonomi Rendah). PKLs are chosen from those who have lived according to their culture so that the information obtained is in accordance with their own point of view and behavior, not a model of thinking from outside (Spradley, 1997). In addition to informants from PKLs, the head of Civil Service and the head of the Regional Public Service Assistance (BLUD) are also appointed as additional informants.

To obtain more accurate data, this study used two data collection techniques, namely observation and interview. Observations were made directly according to the research setting. Researchers try to get involved in every activity related to the daily life of PKLs. The method of observation is intended to observe the types of merchandise, the distribution of merchant locations, daily trading activities from morning to evening, interactions between sellers and buyers, interactions among traders, and types of transactions carried out. All matters related to the information above, are recorded in the form of field notes. Interviews with selected informants were conducted to obtain data about the problem under study. Interviews were conducted by referring to the interview guide in order to facilitate control over the themes under study. Interview guidelines are made 
flexible so that interviews can be developed as detailed as possible to explore issues related to research (Sugiono, 2009). The topics discussed in the interview were related to the economic activities of PKLs, their reasons for selling in groups based on ethnicity, the problems and solutions in overcoming these problems, the strategies implemented so that the PKLs could sustain their business. In conducting interviews, the authors use notebooks, smartphones as tools to collect research data and information.

Data analysis was carried out from the beginning to the end of the study (Spradley in Endraswara, 2003) by determining the parts, the relationship between the parts, and the relationship between the parts and the whole. Data are categorized based on themes obtained in the field. Data analysis was carried out continuously from the initial data collection to the end of the study. The analysis was carried out by compiling the data, then interpreted by referring to the relationship between various concepts and social realities by taking into account the results of observations and interviews.

\section{RESUlts AND DisCUSSION Social and Economic Characteristics of PKLs}

\section{Regions and ethnic groups}

The elements of culture, livelihoods, and economic systems include farmers, fishermen, traders, laborers, craftsmen, employees, and so on. In accordance with this paper, the object of research is PKL. PKLs are an activity carried out as a source of livelihood for ethnic groups who are professionally engaged in this field which can be classified in the form of trading, namely small traders. Most of the PKLs in Kendari City are migrants. They came from various parts of the Indonesian homeland, such as East Java, West Java, Central Java, Palembang, Padang, Makassar, Bone, Raha, Buton, Ambon, Toraja, and others. All of them came with various reasons, namely to find work in Kendari. They are forced to share the joys and sorrows with others who come with the same goal. Only in a matter of time everything changes. They become PKLs, because they think this is a job that is not too difficult, requires a little capital, and makes a decent profit from sales.

Some of the PKLs who trade are villagers who come to the city to earn a living. They have previously known how life in urban areas. They are
PKLs who do not understand the risks of their business. They moved to Kendari because the village where they lived was seen as no longer representative for survival. Generally, they are urban mobility actors, most of the residents who live in the suburbs of Kendari City, such as South Konawe Regency and Konawe Regency. Population mobility carried out by (Mantra in Cangara, 2006) divides population mobility into 3 forms, namely (1) commuting, six hours or more and returning on the same day, (2) staying overnight, more than one day but less than six months, (3) permanent, namely six months or more staying in the destination area. Those who do commuting are vegetable traders who live on the outskirts of the city, namely Abeli, Gunung Jati, and Konda. These commuters are in Kendari from $04.00 \mathrm{am}$ to $17.00 \mathrm{pm}$. They have microbus subscribers that drop them off and pick them up.

Seasonal migrants are traders who sell for a while. This type of PKLs are fluctuating. During the planting or harvest season in rural areas, these PKLs usually decrease, while in the season between planting and harvesting or after harvesting in rural areas, the number of PKLs usually increases. At the time of the research, it happened that the season for fruits, such as durian, rambutan, oranges, and langsat. These fruit traders came from Jati Bali, Sindang Kasih, Landono and Lamonae.

Most of the permanent migrants come from Buton, Raha, Java, Bali, Sumatra, and South Sulawesi. The Ambon riots in 1999 had an impact on the increasing number of PKLs in Kendari City. The Butonese, who was exodus from Ambon, chose to return to their hometown of Buton, but they were involved in a conflict with the Butonese who had long lived in Buton, which was mostly due to cultural differences. To avoid conflict, they prefer to stay and settle in Kendari City.

Migrants from Raha have geographic reasons for coming to Kendari City. Raha's rocky geographical conditions make it impossible to farm, especially for crops of high economic value. Their farming is limited to growing cassava to be made into Kasoami as their daily staple food. They also plant corn during certain seasons which only lasts once a year. The resulting corn is left old for daily consumption as a staple food which they call kambose. A small portion is saved as seed for the next planting season. 
Permanent migrants originating from Java and Bali are generally transmigrants who are placed in several districts in Southeast Sulawesi, including Bombana, Unaaha, and Konawe Selatan districts. Most of the transmigrants remained in the transmigration location as farmers, but some of them prefer to look for work in the cities. Those who trade are generally people who have sold their land. The proceeds from the sale of land are used as capital for trading and living in Kendari City.

Based on research, it is clear that there is a tendency for certain ethnic groups to choose certain types of merchandise as well. People from East Java (Lamongan and Jember) and South Sulawesi (Jeneponto) usually sell seafood. They start selling from $16.00 \mathrm{pm}$ to $03.00 \mathrm{am}$, even until dawn. This ethnic character is more daring, because selling from evening until dawn is vulnerable to risks, either from thugs, drunks, or unpaid customers. The ethnic character has implications for people's views, especially thugs in treating street vendors. The ethnic Makassar, in this case, the Jeneponto people, is highly respected by both fellow street vendors and by thugs. Sellers of groceries, cakes, and yellow rice generally come from South Sulawesi (Bugis). Ambonese and Butonese generally sell accessories, hats, bags, sandals, and shoes. Muna people sell boiled peanuts and fruit. Palembang people sell empek-empek. West and Central Javanese people sell noodles, dumplings, meatballs, fried noodles, martabak, moleng, tahu isi, and terang bulan .

\section{The capital source}

Capital is the amount of money or goods used to start a business. One of the obstacles to PKL is the problem of capital. Capital, either in the form of money or goods is indispensable for starting a business. One of the factors that hinders the development of PKLs is the capital factor. The capital used at the time of opening a business or developing the business is using one's own capital, apart from that it is obtained from social relationships such as gifts from parents or relatives.

Sources of capital vary, from savings within a certain period, or from the sale of inherited assets such as rice fields, fields, gardens, and others. Some obtain capital by borrowing from their parents, relatives and relatives and other people. Sources include, among others, their own capital obtained from wages working at other people's places, cooperatives, credit workers, and BLUD. As expressed by Mr. Yono (45 years), revealed:

"I've been a trader for more than 20 years. I come from East Java, I used to go with my uncle who lived in Kendari who collected scrap metal. But I couldn't bear to work like that, so I ended up joining people selling at Mandonga Market before it caught fire. At first selling, joining people in Mandonga, then the salary given is collected little by little. Alhamdulillah, now it is an independent business, self-managed and selfowned. Fortunately, last night it could reach IDR 250,000. "(Interview, 11 March 2019).

Based on the interview, it can be seen that the PKLs to obtain trading business capital were initially obtained from working at other people's places. They save their wages from helping other people's sales until they are considered sufficient for trading capital. The money is used as initial capital to conduct their own business. In addition to obtaining capital in this way, there are also ways to borrow from family, credit from banks, credit in cooperatives, credit workers, and government assistance through BLUD.

Loans through banks seem a bit difficult for PKLs. Borrowing credit from the bank, where the bank always issues requirements to creditors with guarantees, including land deeds and house deeds as a guide for the bank. The bank will also review the existence of real business owned by a creditor, this is done by the bank so that it does not hesitate in providing venture capital. The existence of bank requirements for prospective creditors makes PKLs have to be prepared for these requirements, so that many PKLs start businesses by collecting money while working, whether they work as pedicab drivers, cart drivers, construction workers and other jobs whose purpose is to raise money to open a trading business. They started small businesses from small businesses to have sufficient assets as if they already had their own trading business.

Kendari City has a government program, namely BLUD (Regional Public Service Assistance) which provides small credit loans to small traders. The number of customers served until February 2018 reached 2,545 people (BLUD office data for 2019). The BLU provides loans without collateral and interest. Initial assistance was given in the amount of IDR. 200,000 in 100 days installments. Now assistance has increased in the 
range of IDR. 500,000 to IDR. 1,000,000 per person,. The loan is paid in installments for 100 days, with installments starting from 5000 plus a service fee of IDR. 280 per day.

To get a BLUD loan, BLUD employees will verify the applicant by surveying the applicant's location. If the applicant has a clear address, a promising business, and is deemed worthy of a loan, the applicant is asked to come to the BLUD office. At the BLUD office, the applicant asked to complete the administration by submitting 5 photocopies of KTP, 3 photocopies of photos, family cards, and filling out personal data forms. After all administrative processes are considered complete, applicants can take out the loan within one week. Some applicants were not served because after the BLUD surveyed the location, their address was unclear or fictitious.

If Some traders could not pay their regular installments, the BLUD staff will visit the merchant's location to ascertain the obstacles faced by the traders. If the arrears in payments are caused by their inadequate income, the trader will be given the opportunity no later than one week to pay off the loan. The BLUD is very helpful for small traders because the loans are provided without collateral and without interest. In contrast to cooperatives or creditors which provide loans with interest and collateral. The working capital for PKL is lower than the formal sector businesses. This indirectly attracts residents to pursue PKL. PKLs have a small income but regularly every day. This is why PKL is in great demand by the community even though the capital turnover is small.

\section{PKLs Strategies to Survive}

The economic crisis in 1997 contributed significantly to the growth of the poor. Facing this situation, community businesses in the informal sector such as PKLs have increased as a form of 'creative efforts in the community to anticipate poverty. Directly or indirectly, they are 'forced' to pursue the informal sector. PKL is an economically affordable option with the hope of surviving in deprived conditions.

They consist of "defeated" social groups. In the village, they are defeated by an impartial situation, for example, limited natural resources. Raha has a geographical condition consisting of rocks, making it impossible to farm, especially for high-economic value crops. The 1997 monetary crisis completed the defeat. They then leave the village because they think their village is no longer suitable as a place to find and care for life. Some of them are outside the region, such as Ambon, Kalimantan, and Makassar. Others migrate to the city of Kendari to work in the informal sector, such as becoming PKL. The urbanization process that takes place above must be appreciated as a creative effort by the people to answer their daily needs. The process of professional transformation from farmers to PKL must be respected as a form of life-saving action.

The "defeated" social groups in urban Kendari did the same. As a result of the monetary crisis that was followed by the employment crisis, they decided to become PKL. This is intended to ensure the sustainability of their life, even though their presence is considered to give chaos to the city. The strategies and efforts made by PKL in maintaining their existence are described as follows:

\section{Trader groupings and inter-trader relations}

PKL in Kendari City can be grouped according to the type of merchandise, for example selling groceries, seafood, used imported goods, vegetables, fish, fruits, food, and others. On the other hand, there is also a sorting of places to sell based on ethnicity and type of sale. PKLs in the park around Kendari Beach who sell Es Teler are Makassarese. The Muna ethnic group that sells vegetables and fruits is called ina-ina. Fish sellers are also Muna people. Bugis people sell used clothes from abroad at the Mandonga Mall Wet Market. The PKLs in front of the port selling groceries are Butonese. The PKL at Puwatu terminal are all Buginese. PKLs around MT. Haryono street is multi-ethnic, but the position in which they trade near each other is based on ethnic similarities. PKL are generally migrants who come from outside the city of Kendari, so the grouping of traders based on ethnicity aims so that they can help each other when there are problems in trading, facilitate access to information related to policing, and also make it easier to return together after selling.

Solidarity between traders due to emotional relationships based on one tribe or village. The trade relations that are built are not just for profit, but also social in nature. The principle of kinship is built among traders from the same area of origin. This principle applies only to those who are truly 
considered family or relatives. This principle is not always interpreted as an economic goal such as seeking profit, but this principle has a social meaning to strengthen relationships between fellow traders.

This kind of life still exists, for example, if a merchant runs out of his merchandise, then they can take the goods to another trader. Borrowing from one another between fellow traders, either in the form of money or merchandise without consideration of profit is common. This kind of relationship includes part of a network of family, friends, or village members. A senior trader Haji Arifin (50 years old) said that:

"If we are together from the village we already consider it as family. We can borrow from each other, sometimes we tell them to take care of what we sell when we go to pray". (Interview, March 5, 2019).

A high sense of solidarity between fellow PKL of one overseas village is very firmly held by PKL. The intensity of their family spirit is higher than when they are in their respective hometowns. In their hometown, they show competition, but overseas what they show is a strong kinship. Kinship relations between fellow villages are not only related to economic issues, but also social issues. When someone in the village dies, they come to express their condolences for the death of the people in their village. Strong family values and high solidarity are also shown at weddings. They came in droves to attend parties from their hometown overseas.

\section{Strategy for dealing with large investors}

PKLs feel treated unfairly by the Kendari City government. The Kendari City Government provides great access and facilities to middle-upper class economic actors to run their businesses, such as providing credit and utilizing city spaces. PKLs with all their limitations, try to survive in the face of big investors for their survival. Even though they do not get the same access as the government, they provide access to the owners of capital who have contributed greatly to the government. In order to compete with cafes or restaurants that prepare franchise food such as KFC (Kentucky Fried Chicken), CFC (California Fried Chicken), Texas, and others, they also prepare counter menus such as Crispy chicken, Kendari Fried Chicken (KFC). Established a tent cafe with comfortable food and service to compete with Cafe Pear (the biggest cafe in Kendari City which is located in the Kadia shopping complex) and the surrounding restaurants. Express photo service to compete with Fuji Image Plaza (FIP) photos. The roadside barbers rival salons and others. All these efforts are carried out by street vendors in order to survive the competition with large capital owners.

Dealing with buyers, merchants always face with soft language, ask for what they want, and don't waste any buyers who come shopping. The phrase that states "the buyer is king" is actually very firmly held by PKLs. Good and harmonious interactions are built into the buyers, thus causing an emotional bond to form between the seller and the buyer which they usually call "langganan" (subscribers). The relationship between seller and buyer is friendly not only because of the ties of the same place of origin and place of residence but also because they have known each other for a long time.

Creating a pleasant atmosphere and flexibility for prospective buyers to choose goods they like is the obligation of the seller. There are several steps that can be taken by the seller to create a pleasant atmosphere for the buyer, namely: 1) Creating an atmosphere of intimate friendship. 2) Provide motivation to consumers to feel that they are important people. 3) Give confidence to himself so that buyers have inspiration or thoughts to buy. 4) Provide a way to make it easier for buyers to make decisions. The seller must understand the buyer's needs, be friendly, friendly, and respect each other.

To create a pleasant atmosphere in attracting buyers' attention, the seller must also approach the buyer if necessary the seller must be able to sell the impression before selling the item. To get the attention of potential buyers, the seller must remember the attitude, language, and way of speaking so that it can make a good impression on the prospective buyer. A pleasant first impression will carry a more intimate impact.

The model of the arrangement of goods and the method of service determine whether the sale is sold or not. Based on the observation of "Pierla Café" which sells various fried foods in Kendari Beach, the dishes offered are very delicious, the atmosphere is made like a cafe because it is equipped with music. There are eight employees who serve visitors in a friendly manner, even the 
owner of the place looks very familiar and has fun chatting with a number of customers who come to eat there. Pierla Cafe is very famous in Kendari City and is very crowded with visitors compared to other places.

PKLs generally choose to sell locations on the sidewalks of the roadside due to the ease of distributing their merchandise, as well as easy access for buyers or visitors. PKLs also sell not far from their homes so that they do not need a car or motorbike to carry goods, simply by using a freight cart. There are also choose a place in front of a shop or on the outskirts of the market because it is crowded. This place is safer because it has the approval of the shop owner. Shop owners are also generally happy because their presence helps to maintain the shop. The shop owner allows it as long as the PKLs maintain cleanliness at the location and do not block vehicles parked in the shop yard.

PKLs are considered to cause problems for the local government, especially with regard to the orderliness, cleanliness, and beauty of the city. In connection with this, according to the Kendari city government, they have prepared a location for the PKLs business, namely on Bypass street, Antero Hamra street, behind Pasar Baru, and the PKLs market on Lawata street. The arrangement of selling locations for PKLs aims to reduce clutter. Admittedly, the implementation has not been effective, because the PKLs are reluctant to occupy the location for various reasons, including being far from the crowd and the location is less strategic. The government has provided a special place for a semi-permanent building located on Antero Hamra street with a rental fee of Rp. 50.000, per month.

Besides selling on the sidewalk, there is a location that is considered strategic by PKLs, namely in a park near Kendari Beach which is right on the side of the main road. Besides being safe, this location has never been evicted by the Kendari City Government even though they sell from 9.00 am to $21.00 \mathrm{pm}$. According to the researcher's analysis, this is due to the amount of fees charged to PKL in this location, which is Rp. 250,000 per month. The government provides facilities in the form of a strategic location and the floors have been cemented.

Based on field research, there are several strategic locations, because the side of the main road is easy to reach by buyers, safe, near the center of the crowd, in front of the hotel, near nightlife spots, in the market. The location includes MT. Haryono street, in the park opposite the Kendari Resik Hotel, in Kendari Beach in front of TWT, around Mandonga Mall, around the market because this place is not in the market, but many buyers make buying and selling transactions in this place.

\section{Conclusion}

The PKLs in Kendari are generally villagers and come to the city to earn a living. They moved to Kendari, because the village where they lived was seen as no longer representative to survive. PKLs are generally urban mobility actors who live on the edge of Kendari City. They have a tendency to select merchandise based on certain ethnic groups. To maintain their existence to survive in the face of fierce business competition, PKLs have different ways, including:

1. Improve relations between fellow street vendors, especially those who have ethnic ties and the same area of origin, so that they can help each other in times of trouble.

2. Improve service by giving a good and pleasant impression to customers.

3. Improve the way of displaying merchandise.

4. Making cheaper 'counter' products.

5. Looking for a strategic location in trading.

\section{REFERENCES}

Boonstra, B., and Boelens, L. (2011). SelfOrganization in Urban Development: Towards a New Perspective on Spatial Planning. Urban Research and Practice. Vol 4(2), pp. 99-122.

(https://www.tandfonline.com/doi/abs/10.108 0/17535069.2011.579767)

Bungin B. (2017). Metodologi Penelitian Kualitatif. Jakarta: Raja Grafindo Persada. Cangara and Saiful. (2006). Pengaruh Difusi Modal dan Lembaga, Internalisasi Nilai Agama Islam dan Budaya Siri Terhadap Keberdayaan Ekonomi dan Karsa dalam Kehidupan Sosial Ekonomi, Disertasi UNPAD tidak dipublikasikan.

Creswell John W and Cheryl N. P (2017). Qualitative Inquiry and Research Design Choosing Among Five Approach. London: SAGE Publications. 
Elias, S., and Noone, C. (2011). The Growth and Development of the Indonesian Economy. Reserve Bank of Australia. (https://www.rba.gov.au/publications/bulletin /2011/dec/pdf/bu-1211-4.pdf).

Endraswara, S. (2003). Metodologi Penelitian Kebudayaan, Yogyakarta: Gadjah Mada University Press.

Handoyo E and Setiawan A B. (2018). PKL as the Survival Strategy of Poor Community. Jurnal Ekonomi dan kebijakan Vol. 1, pp 173-188.

(https://www.researchgate.net/publication/ 323977801_Street_Vendors_PKL_as_the_Su rvival_Strategy_of_Poor_Community)

Handoyo, E., Widyaningrum, N. R. (2015). Relocation as Empowerment: Response, Welfare, and Life Quality of PKLs After Relocation. International Journal of Indonesian Society and Culture, Vol 7(1), pp. 30-42

(https://journal.unnes.ac.id/nju/index.php/ko munitas/article/view/3428)

Irianto A.M. (2014). Strategi Adaptasi PKL Kota Semarang: Kajian Tentang Tindakan Sosial. International Journal of Indonesian Society and Culture, Vol. 6(1), pp. 70-90.

(https://journal.unnes.ac.id/nju/index.php/ko munitas/article/view/2938 )

Lexi J.Moleong. (2015). Metodelogi Penelitian

Kualitatif, Bandung: PT Remaja

Rosdakarya.

Maneepong, C., and Walsh, J. C. (2013). A New Generation of Bangkok PKLs: Economic Crisis as Opportunity and Threat. Cities, Vol 34, pp. 37-43.

(https://www.researchgate.net/publication/25 9934427)

Maxwell and Joseph A. (1996) Qualitative

Research Design An Interactive Approach. London: SAGE Publications.

(https://www.researchgate.net/publication/32 0353627)

Nursyirwan E, (1997). Pasar dan Fungsi

Kebudayaan dalam Koentjaraningrat dan

Antropologi di Indonesia, Jakarta.

Naim, and Muchtar. (1984). Merantau; Pola

Migrasi Suku Minangkabau, Yogyakarta, UGM Press.
Roberts, Brian, and Trevor Kanaley. (2006). Overview: Urbanization and Sustanibilty in Asia Case Study of Good Practice. Philippines: Asian Development Bank.

(https://www.adb.org/sites/default/files/publi cation/27965/urbanization-sustainability.pdf)

Sariffuddin, Wahyono H, and Brotosunaryo. (2017). Street Vendors Hypergrowth: Consequence of Uncontrolled Urbanization in Semarang City, International Journal of Indonesian Society and Culture Vol 9(1), pp 81-91. (https://journal.unnes.ac.id/nju/index.php/ko munitas/article/view/8497)

Spradley, and James P. (1997). The Etnographic Interview", dalam Metode Etnografi. Yogyakarta: Kanisius.

Sugiyono. (2008). Understanding Qualitative Research. Bandung: Alfabeta.

World Bank. (2012). The Rise of Metropolitan Regions: Towards Inclusive and Sustainable Regional Development. (https://www.researchgate.net/publication/28 2701827). 